\title{
PARASITIC AND MICROBIAL INFESTATIONS OF FRUITS SOLD AT OTUOKE, OGBIA LOCAL GOVERNMENT AREA, BAYELSA STATE, NIGERIA
}

\section{Ezenwaka Chinonye O.* and Amuzie Chidinma C.}

\author{
${ }^{1}$ Department of Biology, Faculty of Science, Federal University Otuoke, Bayelsa State, \\ Nigeria. \\ ${ }^{2}$ Parasitology and Entomology Laboratory, Department of Animal and Environmental \\ Biology, Rivers State University, Port Harcourt, Nigeria. \\ ${ }^{*}$ Corresponding Author Email: chyladyn@yahoo.com
}

\section{Cite this article:}

Ezenwaka C.O., Amuzie C.C. (2021), Parasitic and Microbial Infestations of Fruits Sold at Otuoke, Ogbia Local Government Area, Bayelsa State, Nigeria. African Journal of Biology and Medical Research 4(2), 57-66. DOI: 10.52589/AJBMRCVMISJRL.

\section{Manuscript History}

Received: 18 March 2021

Accepted: 14 April 2021

Published: 20 May 2021

Copyright $\odot 2020$ The Author(s). This is an Open Access article distributed under the terms of Creative Commons Attribution-NonCommercialNoDerivatives 4.0 International (CC BY-NC-ND 4.0), which permits anyone to share, use, reproduce and redistribute in any medium, provided the original author and source are credited.
ABSTRACT: Fruits and vegetables have numerous health importance but can act as vehicles in the transmission of foodborne diseases of public health importance. This research examined the presence of parasites and microbial organisms on fruits sold at Otuoke community, Ogbia Local Government Area, Bayelsa State, Nigeria using six fruits types, including pineapple (Ananas comosus), cucumber (Cucumis sativus), lime (Citrus aurantiifolia), garden egg (Solanum aethiopicum), guava (Psidium guajava) and orange (Citrus sinensis). The parasites were concentrated by sedimentation and were examined using a light microscope. The result of the study showed the presence of cysts of Cryptosporidium parvum, Entamoeba histolytica, eggs of Fasciola hepatica, Ascaris lumbricoides and larva of Strongyloides stercoralis. Five out of the 6 fruits types examined were infested with at least one type of parasites. Ascaris lumbricoides (33.33\%) was the most frequently detected parasite and was found on the pineapple, guava and oranges fruits. Fruit types were not significantly associated with parasitic contamination $(p>0.005)$. Bacteria isolated from the fruits included Lactobacillus sp., Proteus mirabilis, Bacillus subtilis, Pseudomonas sp., Bacillus cereus, Salmonella typhi, Shigella sp., Escherichia coli and Staphylococcus aureus. E. coli was isolated in all the sampled fruits types. The total count was determined by pour plate method using MacConkey agar. Total viable bacteria count (TBC) ranged from $21.9 \times 10^{5} \mathrm{cfu} / \mathrm{ml}$ to $7.27 \times 10^{5} \mathrm{cfu} / \mathrm{ml}$. Aspergillus niger, A. flavus, Mucor spp.. and Fusarium spp were the isolated fungi species. A high number of these microorganisms in fruits and vegetables can lead to public health emergencies. Risk reduction can be achieved through personal and food hygiene by the fruit sellers and consumers. Further studies should be conducted to address the effect of seasonal variation on the infestation of the fruits sold in this area.

KEYWORDS: Parasites, Bacteria, Fruits, Fungi, Microbial, Public Health, Bayelsa. 


\section{INTRODUCTION}

The importance of fruits and vegetables in nutrition and health is well known. In recent years many countries have undertaken numerous approaches to encourage people to increase their quantity of fruit intake (Tetens and Alini, 2009). Fruits are very important sources of essential vitamins and are vital for the well-being of humans. They boost host immunity and also contain antioxidants and fibre (Eni et al., 2010; Whitney-Chanex, 2011). A balanced diet rich in fruits has been used to reduce the risk of several diseases (Kalia and Gupta, 2006) such as cardiovascular diseases, cancers, strokes as well as functional retardation associated with ageing (Rui, 2003).

Despite the numerous health benefits derived from fruits and vegetables, they sometimes act as a vehicle in the transmission of infectious diseases, causing foodborne diseases of public health importance (Hannan et al., 2014), resulting in morbidity and mortality (Hanson et al., 2012). Studies (Wedajo and Kadire, 2019; Adamu et al., 2012) have shown that the fact that fruits and vegetables can transmit infectious organisms and pose a great health threat. Pathogenic organisms can enter fruits through damaged surfaces such as punctures, wounds, cuts and splits that occur during growth, harvesting or handling (Durgesh et al., 2008). Infective stages of helminth parasites most commonly contaminate fruits and vegetables, as they are abundant in the environment (Luka et al., 2016). Conditions that predispose humans to contaminated fruits and vegetables are predominantly found in Africa where there is generally poor hygiene and sanitation. Pieces of evidence abound of the increased risk of infection with parasitic organisms in areas, including Nigeria, where untreated wastewater is being used for the irrigation of fruits and vegetable (Ekwunife and Akolisa, 2009, Adamu et al., 2012, Amawulu et al., 2019). Animal dung is used as manure and the poor sanitary habit of eating fruits without washing contribute to the spread of these diseases. Most fruit sellers use poor quality water to wash the fruits before sales to the consumers, thereby exposing them to the risk of both microbial and parasitic infections. The prevalence and magnitude of parasitic and microbial contamination of food products vary from one area to another (Dawet et al., 2019).

Presently, there is no published information about the level of parasitic and microbial infestation of fruits sold in Otuoke Community in Ogbia Local Government Area of Bayelsa State. Therefore, this study was undertaken to determine the level of parasitic and microbial infestations of selected fruits in this area and make available baseline data from this study in the area to create awareness to the public and for the appropriate agencies to work with.

\section{MATERIALS AND METHODS}

\section{Study Area}

Otuoke town in Ogbia Local Government Area, Bayelsa State, Nigeria, is located approximately at Latitude $4{ }^{\circ} 49 \mathrm{~F}$ North and Longitude $6^{\circ} 20 \mathrm{~F}$ East. It is bounded to the east by Emeyal 1 and Kolo; to the west by Onuebum and Otuogori and to the south by Otuaba and Ewoi communities, all in Ogbia Local Government Area of Bayelsa State, Nigeria. It has a wet terrain with a fairly good road network. The prevalent climatic condition in the area is marked by rainy and dry seasons. The rainy (wet) season is from April to October while the dry season starts in November to March. The average monthly temperatures are high throughout the year. Farming and fishing are the main occupations of the indigenes while a majority of the non- 
indigenes are traders. Both indigenous and non-indigenous residents in Otuoke eat fresh fruits. Fruit sellers in Otuoke mostly get their fruits supplies directly from the local farmers while some sellers often go to some other markets to purchase, ensuring all-round supply. People from other nearby communities buy fruits from these sellers when on a visit to family and friends.

\section{Sample Collection}

Six different types of fruits were examined for infestation with parasites and pathogenic microorganisms. The fruit sampled included garden egg (Solanum aethiopicum), orange (Citrus sinensis), cucumbers (Cucumis sativus L.), lime (Citrus aurantiifolia), guava (Psidium guajava L.) and pineapple (Ananas comosus) which were randomly bought from the sellers in the study area. All the samples were collected in sterile universal plastic bags and transported to the Laboratory in the Department of Microbiology, Federal University, Otuoke, Bayelsa State for analysis.

\section{Parasitological Examination}

As soon as the samples were brought into the laboratory, $10 \mathrm{~g}$ of each fruit was washed in a sterile beaker containing $250 \mathrm{ml}$ of sterile distilled water and saline solution for the removal of parasitic ova, cysts and larva as described by Awe and Madueke (2015). The water use in washing each of the fruits was allowed to stand for 20 minutes. The suspension was sieved using a sterile sieve to remove any unwanted materials. The filtrate was centrifuged at $3000 \mathrm{rmp}$ for five minutes in plastic test tubes and the supernatant, discarded. The supernatant was decanted, leaving the sediment which was mixed and examined under a light microscope using $\times 10$ and $\times 40$ objectives. The parasites detected were identified using an identification key (Cheesbrough, 2006),

\section{Bacterial and Fungal Examination}

The samples were aseptically chopped into smaller pieces using a sterile stainless steel knife prior to weighing. A $10 \mathrm{~g}$ of a subsample of each vegetable was aseptically weighed and vigorously shaken in $90 \mathrm{ml}$ of sterile $0.1 \%(\mathrm{w} / \mathrm{v})$ buffered peptone water for 3min separately to homogenize the samples (Shalini, 2010).

For enumeration of microorganisms present in each sample, 10-fold serial dilutions of the resultant homogenates were made. Sterile test tubes were labelled as $\left(10^{-1}, 10^{-2}, 10^{-3}, 10^{-4}\right.$ and $10^{-5}$ ) for each sample. One milliliter $(1 \mathrm{ml})$ of the sample was added into $9 \mathrm{ml}$ of sterile normal saline $\left(10^{1}\right)$ and mixed properly in order to get equal distribution of microorganisms. The procedure was repeated to complete the serial dilution up to $10^{-5}$. Nutrient agar, MacConkey agar, Salmonella-Shigella agar and Potato Dextrose agar were prepared according to manufacturers' instruction. The freshly prepared and cooled media were poured into sterile flat-bottomed Petri dishes on a levelled, horizontal surface to give a uniform depth of approximately $4 \mathrm{~mm}$. This was achieved by pouring $20 \mathrm{ml}$ of the medium for plates with diameters of $100 \mathrm{~mm}$.

\section{Total Coliform Count}

The total count was determined by pour plate method using MacConkey agar as the primary choice of medium. $1 \mathrm{ml}$ of $10^{-4}$ dilution was pipetted into the centre of the petri-dish, using a 
fresh pipette for each dilution. The agar was poured into the plates aseptically, enough to cover the $1 \mathrm{ml}$ solution in them. The plate was rocked and allowed to solidify. It was inverted and incubated at $37^{\circ} \mathrm{C}$ for 24 hours. The colonies on the plates were then counted with a colony counter.

Biochemical tests such as Catalase test, Citrate utilization test, Indole test, Coagulase test, Oxidase test and Motility test were performed for the identification of the bacteria isolated from the fruits (Cheesebrough, 2006).

\section{Identification of Fungi Isolate}

After incubation, different types of fungi species and mucor growths were formed on the surface of the potato dextrose agar. The fungal isolates were identified by direct observation with unaided eyes and identification of microscopic features with the microscope.

\section{Statistical Analysis}

Results were presented as means \pm standard error (SE). The percentage frequency was also determined. Data differences were determined using one-way ANOVA. The minimum significance level was $\mathrm{p}<0.05$. All analysis was carried out using SPSS version 20.

\section{RESULT}

Six different types of fruits including pineapple (Ananas comosus), cucumber (Cucumis sativus), lime (Citrus aurantiifolia), garden egg (Solanum aethiopicum), guava (Psidium guajava) and orange (Citrus sinensis) were examined for parasitic and microbial organisms. The result of the parasitological examination showed that cysts, eggs and larva of parasites were recorded. Five out of the 6 fruits types examined were contaminated with at least one type of parasites. Helminths and protozoan parasites were encountered (Strongyloides stercoralis, Cryptosporidium parvum, Fasciola hepatica, Ascaris lumbricoides, Entamoeba histolytica). Ascaris lumbricoides (33.33\%) was the most frequently detected parasite and was found on the pineapple, guava and oranges fruits. Cryptosporidium parvum (20\%) was found only on cucumbers. Garden egg was found to be infested with Strongyloides stercoralis (66.67) and Fasciola hepatica $(33.33 \%)$. There was no parasite found on the lime. Fruit types were not significantly associated with parasitic contamination $(p>0.005)$ (Table 1$)$.

Table 1: Frequency of distribution of parasite species on fruits sampled at Otuoke, Bayelsa State, Nigeria.

\begin{tabular}{|l|l|l|l|l|l|l|l|}
\hline \multirow{2}{*}{ Parasites } & \multicolumn{9}{|l|}{ Fruit Types } \\
\cline { 2 - 8 } & $\begin{array}{l}\text { Pineappl } \\
\mathrm{e}(\%)\end{array}$ & $\begin{array}{l}\text { Cucumber } \\
(\%)\end{array}$ & $\begin{array}{l}\text { Lime } \\
(\%)\end{array}$ & $\begin{array}{l}\text { Garden egg } \\
(\%)\end{array}$ & $\begin{array}{l}\text { Guava } \\
(\%)\end{array}$ & $\begin{array}{l}\text { Orange } \\
(\%)\end{array}$ & $\begin{array}{l}\text { Total } \\
(\%)\end{array}$ \\
\hline $\begin{array}{l}\text { Strongyloides } \\
\text { stercoralis }\end{array}$ & $0(0)$ & $0(0)$ & $0(0)$ & $2(66.67)$ & $0(0)$ & $1(50)$ & $3(20)$ \\
\hline $\begin{array}{l}\text { Cryptosporidiu } \\
\text { m parvum }\end{array}$ & $0(0)$ & $3(75)$ & $0(0)$ & $0(0)$ & $0(0)$ & $0(0)$ & $3(20)$ \\
\hline $\begin{array}{l}\text { Fasciola } \\
\text { hepatica }\end{array}$ & $1(33.33)$ & $0(0)$ & $0(0)$ & $1(33.33)$ & $0(0)$ & $0(0)$ & $2(13.33)$ \\
\hline
\end{tabular}


African Journal of Biology and Medical Research

ISSN: 2689-534X

Volume 4, Issue 2, 2021 (pp. 57-66)

www.abjournals.org

\begin{tabular}{|l|l|l|l|l|l|l|l|}
\hline $\begin{array}{l}\text { Ascaris } \\
\text { lumbricoides }\end{array}$ & $2(66.67)$ & $0(0)$ & $0(0)$ & $0(0)$ & $2(66.67)$ & $1(50)$ & $5(33.33)$ \\
\hline $\begin{array}{l}\text { Entamoeba } \\
\text { histolytica }\end{array}$ & $0(0)$ & $1(25)$ & $0(0)$ & $0(0)$ & $1(33.33)$ & $0(0)$ & $2(13.33)$ \\
\hline Total & $3(100)$ & $4(100)$ & $0(0)$ & $3(100)$ & $3(100)$ & $2(100)$ & $15(100)$ \\
\hline
\end{tabular}

Nine species of bacteria isolated and identified from the fruits included Lactobacillus sp., Proteus mirabilis, Bacillus subtilis, Pseudomonas sp., Bacillus cereus, Salmonella typhi, Shigella sp., Escherichia coli and Staphylococcus aureus. E. coli was seen in all the sampled fruits types while Lactobacillus spp was isolated only from guava. The results indicated that Proteus mirabilis, Shigella spp. and E. coli were obtained from the pineapples; B. subtilis, $S$. typhii, Shigella spp., and E. coli were recovered from cucumber; P. mirabilis, Pseudomonas spp., S. typhii, E. coli and S. aureus were found on the limes. Bacillus cereus, S. typhii, Shigella spp. and E. coli were recovered from the garden eggs, while Pseudomonas spp., S. typhi, Shigella spp and E. coli were found on the oranges (Table 2).

Table 2: Micro-organisms isolated from fruit types sold at Otuoke, Bayelsa State, Nigeria

\begin{tabular}{|l|l|l|l|l|l|l|}
\hline \multirow{2}{*}{ Bacteria spp. } & \multicolumn{7}{|c|}{ Fruit Types. } \\
\cline { 2 - 8 } & Pineapple & Cucumber & Lime & Garden egg & Guava & Orange \\
\hline $\begin{array}{l}\text { Lactobacillus } \\
\text { spp. }\end{array}$ & - & - & - & - & + & - \\
\hline Proteus mirabilis & + & - & + & - & - & - \\
\hline Bacillus subtilis & - & + & - & - & - & - \\
\hline $\begin{array}{l}\text { Pseudomonas } \\
\text { spp. }\end{array}$ & - & - & + & - & - & + \\
\hline Bacillus cereus & - & - & - & + & - & - \\
\hline Salmonella typhi & - & + & + & + & + & + \\
\hline Shigella spp. & + & + & - & + & + & + \\
\hline Escherichia coli & + & + & + & + & + & + \\
\hline $\begin{array}{l}\text { Staphylococcus } \\
\text { aureus }\end{array}$ & - & - & + & - & + & - \\
\hline
\end{tabular}

Key: $(+)=$ present; $(-)=$ absent

The mean total viable bacteria count $(\mathrm{cfu} / \mathrm{ml})$ showed that pineapple $\left(21.9 \pm 4.9 \times 10^{5} \mathrm{cfu} / \mathrm{ml}\right)$ had the highest mean microbial load followed by guava $\left(11.5 \pm 4.4 \times 10^{5}\right)$ and cucumber $\left(10.9 \pm 4.9 \times 10^{5} \mathrm{cfu} / \mathrm{ml}\right)$ while lime $\left(7.27 \pm 6.1 \times 10^{5} \mathrm{cfu} / \mathrm{ml}\right)$ had the least mean. The total coliform count $(\mathrm{TCC})(\mathrm{cfu} / \mathrm{ml})$ revealed that pineapple $\left(7.7 \pm 4.0 \times 10^{5} \mathrm{cfu} / \mathrm{ml}\right)$ had the highest mean value followed by garden eggs $\left(7.37 \pm 3.5 \times 10^{5} \mathrm{cfu} / \mathrm{ml}\right)$ and guava $\left(7.0 \pm 3.5 \times 10^{5} \mathrm{cfu} / \mathrm{ml}\right)$. Pineapple $\left(9.0 \pm 3.2 \times 10^{5} \mathrm{cfu} / \mathrm{ml}\right)$ again had the highest mean total Salmonella-Shigella count (TSSC) followed by cucumber $\left(7.16 \pm 4.9 \times 10^{5} \mathrm{cfu} / \mathrm{ml}\right)$ while garden egg $\left(4.57 \pm 6.6 \times 10^{5} \mathrm{cfu} / \mathrm{ml}\right)$ had the least. Total fungal count (TFC) revealed guava $\left(5.2 \pm 4.6 \times 10^{5} \mathrm{cfu} / \mathrm{ml}\right)$ had the highest mean TFC followed by lime $\left(3.36 \pm 6.9 \times 10^{5} \mathrm{cfu} / \mathrm{ml}\right)$ while orange had the least $\left(1.1 \pm 1.7 \times 10^{5} \mathrm{cfu} / \mathrm{ml}\right)$ (Table 3). 
African Journal of Biology and Medical Research

ISSN: 2689-534X

Volume 4, Issue 2, 2021 (pp. 57-66)

www.abjournals.org

Table 3: Total Microbial Load Count from Fruit sold at Otuoke, Bayelsa State, Nigeria

\begin{tabular}{|l|l|l|l|l|}
\hline Fruit types & TBC $(\mathrm{cfu} / \mathrm{ml})$ & TCC $(\mathrm{cfu} / \mathrm{ml})$ & TSSC(cfu/ml) & TFC(cfu/ml) \\
\hline Pineapple & $21.9 \pm 4.9 \times 10^{5}$ & $7.7 \pm 4.0 \times 10^{5}$ & $9.0 \pm 3.2 \times 10^{5}$ & $2.3 \pm 3.2 \times 10^{5}$ \\
\hline Cucumber & $10.9 \pm 4.9 \times 10^{5}$ & $6.47 \pm 4.7 \times 10^{5}$ & $7.16 \pm 4.9 \times 10^{5}$ & $1.16 \pm 3.2 \times 10^{5}$ \\
\hline Lime & $7.27 \pm 6.1 \times 10^{5}$ & $4.5 \pm 4.9 \times 10^{5}$ & $5.4 \pm 4.7 \times 10^{5}$ & $3.36 \pm 6.9 \times 10^{5}$ \\
\hline Garden egg & $8.9 \pm 6.1 \times 10^{5}$ & $7.37 \pm 3.5 \times 10^{5}$ & $4.57 \pm 6.6 \times 10^{5}$ & $1.5 \pm 3.2 \times 10^{5}$ \\
\hline Guava & $11.5 \pm 4.4 \times 10^{5}$ & $7.0 \pm 3.5 \times 10^{5}$ & $6.07 \pm 5.5 \times 10^{5}$ & $5.2 \pm 4.6 \times 10^{5}$ \\
\hline Orange & $10.3 \pm 4.9 \times 10^{5}$ & $5.77 \pm 5.2 \times 10^{5}$ & $5.7 \pm 3.2 \times 10^{5}$ & $1.1 \pm 1.7 \times 10^{5}$ \\
\hline
\end{tabular}

$\mathrm{TBC}=$ Total viable bacterial count, $\mathrm{TCC}=$ Total coliform count, TSSC $=$ Total Salmonella shigella count, TFC $=$ Total fungal count

Four fungal species were found on the fruits and vegetables, namely, Aspergillus niger, A. flavus, Mucor spp. and Fusarium spp. The presence of A. flavus and Fusarium spp was identified in pineapples; Fusarium spp in cucumber; A. niger and Fusarium spp in lime; $A$. niger, Mucor, Fusarium; in garden eggs spp. and guava, Fusarium spp., while Fusarium spp was seen in orange (Table 4).

Table 4: Fungal species isolated from fruits types sampled at Otuoke, Bayelsa State, Nigeria

\begin{tabular}{lllllll}
\hline Fungi & Pineapple & Cucumber & Lime & Garden egg & Guava & Orange \\
\hline $\begin{array}{l}\text { Aspergillus } \\
\text { niger }\end{array}$ & - & - & + & + & - & - \\
$\begin{array}{l}\text { Aspergillus } \\
\text { flavus }\end{array}$ & + & - & - & - & - & - \\
Mucor spp. & - & - & - & + & - & - \\
Fusarium spp. & + & + & + & + & + & + \\
\hline
\end{tabular}

Key: $(+)=$ positive; $(-)=$ negative.

\section{DISCUSSION}

Results from this study indicated that the fruits were contaminated by various pathogenic organisms such as parasites (S. stercoralis, C. parvum, F. hepatica, A. lumbricoides and E. histolytica), bacteria (Lactobacillus sp., Proteus mirabilis, Bacillus subtilis, Pseudomonas sp., Bacillus cereus, Salmonella typhi, Shigella sp., Escherichia coli and Staphylococcus aureus and fungi (Aspergillus niger, A. flavus, Mucor spp. and Fusarium spp).

The findings of this study corroborate with those of Asghar et al., (2013), Dada and OlusolaMakinde (2015) and Wedajo and Kadire (2019) who also discovered the presence of both parasites and microbes in fruits and vegetables. Istifanus \& Panda (2018) in their study in Bauchi State noted the contamination of vegetables and fresh fruits with various parasitic cysts and ova. Amawulu et al., (2019) confirmed the infestation of fruits (20\%) sold in Yenagoa, Bayelsa State Capital, with parasites. Tefera et al., (2014) isolated Cryptosporidium species, Hymenolepis nana, Giardia lamblia, Ascaris lumbricoides and Entamoeba histolytica dispar from fruits in southwest Ethiopia. Ascaris lumbricoides (33.33\%) was the most frequently 
detected parasite in this study. This is similar to Istifanus \& Panda (2018) report of Ascaris lumbricoides being the most prevalent parasitic contamination in both vegetables and fruits in his study. Hassan et al., (2013) reported the least infestation in his study for lime fruit. This is not far from no infestation recorded for lime in this study. Hassan et al., (2013) opined that, though lime has a rough surface that may seem to support parasite attachment, other factors apart from skin surface texture might be in play to enhance or inhibit parasite occurrence on fruits and vegetables.

The parasites detected in this study are of very high public health importance. It had been reported that Nigeria has a very high prevalence of gastrointestinal helminths infection, especially in children (Living-Jamala et al., 2018; Lorina, 2013; Ihesiulor et al., 2013), which have detrimental effects on the growth, physical fitness and cognitive performance of the infected children. The eggs, cysts or larvae of the parasites contaminate the soil or fruits and vegetable through open defecation or the use of infected faeces as night soil. The eggs are ingested by humans through the consumption of contaminated food, soil and drinking water (Kayser et al., 2005). The occurrence of A. lumbricoides in some stream, river and other sources of water has been reported by Nwele et al., (2013) and Solomon et al., (2013) which is also a predisposing factor to the contamination of fruits when such water is used for irrigation and washing of the fruits. The presence of the eggs of $F$. hepatica could be an indication of the presence of water or soils polluted by cattle dung. The washing of fruits in already contaminated water gives more room for parasite cysts, larvae and ova of parasites to be transmitted to the fruits. The rate of infection with parasites is generally high among people who have poor personal and environmental hygiene (Naish et al., 2004). Proper washing of fruits and vegetables may reduce microbial and parasitic contaminations. Also, filthy environment and refuge heaps constitute means of contamination for fruits even at the point of sale where these edible fruits are displayed. Flies can mechanically transfer parasites cyst and ova from dirt to already displayed fruits.

The relatively high microbial load of microorganisms gotten from fruits and vegetables could perhaps be linked to the unhygienic condition of point of sale or transport systems. Improper handling of fruits by sellers could also be a source of contamination. Most sellers mix contaminated fruits with good ones during storage leading to the spread of bacteria from contaminated fruits to the good ones. Buck et al., (2003) stated that the presence of many pathogens in the soil is from environmental sources such as faeces or untreated sewage, and microorganisms present in the soil or water can be the source of contamination for fruits and vegetables. The slight variation in the microbial load from other sources could be traced to possible pre-washing of fruits by the fruit sellers before display. Duedu et al., (2014) has shown that washing vegetables with just water was not enough to remove any contaminating parasites.

The isolation of bacteria such as Staphylococcus aureus, Bacillus subtilis, Bacillus cereus, Escherichia coli, Proteus mirabilis, Pseudomonas sp., Salmonella typhi, Shigella spp, Lactobacillus spp and fungi such as Mucor spp, Fusarium spp, Aspergillus niger and Aspergillus flavus shows that fruits could act as a medium for the spread of both pathogenic and opportunistic microbes. These isolated organisms have also been reported by Ankita et al., (2014) and Eni et al., (2010). The isolation of Escherichia coli (coliforms) and Proteus mirabilis (enteric bacteria) from fruits suggested their likelihood of faecal contamination (IssaZacharia et al., 2010); they could also arise from the use of human faeces as manure. Also, isolation of environmental isolates such as Pseudomonas, Bacillus and Aspergillus spp, may be indicative of soil contamination. Pseudomonas spp. is also associated with spoilage of 
vegetable and fruits. Bacillus spp. are part of the normal soil flora, occurring in vegetables and fruits that are not handled properly, causing foodborne disease and vegetable spoilage (Michael et al., 2005).

The fungus isolate- Mucor sp. has been indicated to cause food spoilage while growing on fruits and vegetables (Michael et al., 2005). Aspergillus niger is a common environmental contaminant, forming spore (Michael et al., 2005), and has been implicated in foodborne diseases (Akinleye et al., 2013). Baiyewu et al., (2007) reported that Aspergillus flavus, Aspergillus niger and Fusarium spp etc, were responsible for post-harvest losses in pawpaw in Nigeria.

Variations in geographical locations, climatic and environmental conditions, the kind of sample and sample size examined, the sampling techniques, methods used for detection of the organisms, type of water used for washing before display by the sellers and contamination extent of irrigation water might bring any noted variation between the result of this study and previous studies. Consequently, the variation of the results would be expected so long as these factors differ.

\section{CONCLUSION}

This study has revealed various parasites of public health and agricultural importance. A high number of these microorganisms in fruits can lead to public health emergencies resulting in infections with singular or combined symptoms reflecting the pathogens involved. Risk reduction can be achieved through personal and food hygiene. Relevant agencies should make every effort to educate the local populace on the importance of attitudinal change to reduce the rate of parasitic contamination of these commodities and the environment. Further studies should be conducted to address the effect of seasonal variation on the infestation of the fruits sold in this area.

\section{Conflict of Interests}

The authors declare no conflict of interest

\section{REFERENCES}

Adamu, N. S., Adamu, J. Y. \& Mohammed, D. (2012). Prevalence of helminths parasites on vegetables sold in Maiduguri, Northeastern Nigeria. Food Control, 25(1), 23-26

Akinyele, B. J., Oladejo, B. O., Bankefa, E. O., \& Ayanyemi, S. A. (2013). Microbiological post-harvest diseases and aflatoxin contamination of marketed Pawpaw fruit (Carica papaya $\mathrm{L}$ ) in South-Western vegetables collected from retailers in main market, Akure, Nigeria. American Journal of Microbiological Research, 3(3), 112-117.

Dawet, A., Ipadeola, R. B., Yakubu, D. P, Danahap, L. S., \& Agbalaka, P. I. (2019). Parasitic contamination of some fruits, vegetables, and nuts sold in Jos, Plateau State, Nigeria. International Research Journal of Public and Environmental Health, 6 (7), 135-143. 
Duedu, K. O., Yarnie, E. A., Tetteh-Quarcoo, P. B., Attah, S. K., Donkor, E. S., \& AyehKumi, P. F. (2014). A comparative survey of the prevalence of human parasites found in fresh vegetables sold in supermarkets and open-aired markets in Accra, Ghana. BMC research notes, 7,1 .

Durgesh, P.M., Ranjana, G.K., \& Varsha, K.V. (2008). "Microbiological analysis of street vended fruit juices from Mumbai city, India". Internet Journal of Food Safety, 10, 31 34.

Ekwunife, C. A., \& Akolisa, I. C. (2009). Geohelminth contamination of some common fruits and vegetables sold in Onitsha urban, south-east, Nigeria. The Zoologist, 7, 96101.

Eni, A. O., Oluwawemitan, I. A. \& Oranusi, U. S. (2010). "Microbial quality of fruits and vegetables sold in Sango Ota, Nigeria". African Journal of Food Science, 4(5), 291296.

Hannan, A., Rehman, R., Saleem, S., Khan, M. U., Qamar, M. U. \& Azhar, H. (2014). "Microbiological Analysis of Ready-to-eat Salads Available at Different Outlets in Lahore, Pakistan". International Food Research Journal, 21(5), 1797-1800.

Hanson, L.A., Zahn, E.A., Wild, S.R., Döpfer, D., Scott, J., \& Stein, S. (2012). "Estimating Global Mortality from Potentially Foodborne Diseases: An Analysis Using Vital Registration Data". Population Health Metrics, 10 (5), 7-12.

Hassan, A. A., Ojuromi, O. T. ,\& Onyeahialam, O. (2013). Presence of Parasitic Ova, Cysts and Larvae on common fresh fruits and vegetables sold at some major markets in Ibadan, Oyo State, Nigeria. The Zoologist, 11, 40-45.

Ihesiulor, G. U., Kashibu, E., Azeez- Akande, O., Imoru, M . (2013). Helminths of the gastrointestinal tract among children in Kano, Northern Nigeria. Asian Journal of Biological and Life Sciences, 2(2), 122-126.

Issa-Zacharia, A., Kamitani, Y., Muhimbula, H. S., \& Ndabikunze, B. K. (2010). “A Review of Microbiological Safety of Fruits and Vegetables and the Introduction of Electrolyzed Water as an Alternative to Sodium Hypochlorite Solution". African Journal of Food Science, 4(13), 778-789.

Istifanus, W. A., \& Panda, S. M. (2018). Parasitic Agents in fresh fruits and vegetables sold in open markets in Bauchi, Nigeria. Journal of Food Quality and Hazards Control, 5, 84-88.

Kalia, A. \& Gupta, R. P., (2006). "Fruit Microbiology". Handbook of Fruit and Fruit processing, 1st Edition, Blackwell publishing, 3-28.

Kayser, F. H., Bienz, K. A., Eckert, J. \& Zinkernagel, R. M. (2005). Medical Microbiology. Thieme Stuttgart, New York. 2005, 10th German Ed, 571-578.

Living-Jamala, U., Eze, N. C., \& Nduka, F. O. (2018). Prevalence and Intensity of Intestinal Helminth Infections and Associated Risk Factors among School-Aged Children in Abua/Odual Local Government Area, Rivers State. Journal of Applied Life Sciences International, 16(2), 1-7.

Lorina, I. E. (2013). Prevalence of intestinal helminthic infection among school children in rural and semi-urban communities in Nigeria. Journal of Dental and Medical Sciences, $6(5), 61-66$

Luka, J., Biu, A. A., Babayo, A. M., Kyari, F., Mohammed, Y. M., Sonibare, A. O. (2016). Prevalence of helminths on raw vegetables and hygienic practices among vegetable marketers in Maiduguri, Borno State, Nigeria. Nigerian Journal of Parasitology. 37(2), 169-73. 
Michael, J., Pelczar., E. C. S., Chan\& Noel, R. Krieng (2005). Microbiology, New Delhi, Tata McGraw Hill, 5th Ed., 793-811.

Naish, S., McCarthy, J., \& Williams, G. M. (2004). Prevalence, intensity and risk factors for soil-transmitted helminth infection in a South Indian fishing village. Acta Tropic. 91, 177-87.

Nwele, D. E., Uhuo, A. C., Okonkwo, E. C., Ibiam, G. A., Onwe, C. S., Ugwu. J. I., Onwe, J. C. and Nwuzo, A. C (2013). Parasitological examination of Ava stream used in irrigation in Enugu State, South- Eastern Nigeria: An implication for helminth transmission. Journal of Parasitology and Vector Biology, 5(8), 112-115.

Rui, H. L., (2003). "Health Benefits of Fruit and Vegetables are from Additive and Synergistic Combinations of Phytochemicals". Journal of Clinical Nutrition, 78, 517519.

Shalini, S. (2010)., Study on Microbiological Aspects of Fresh Fruit and Vegetables (Including Green Leafy Vegetables) in and around National Capital Region (NCR), Bhaskaracharya College of Applied Sciences, New Delhi, India, 2010.

Solomon, C., Michael, U., Bitrus, J., Micheal, A., Aloysius, U., Godwin, O., Joan, P., Richard A. \& Joseph, A. (2013). Parasitological Evaluation of Domestic Water Sources in a Rural Community in Nigeria. British Microbiology Research Journal, 3(3), 393399.

Tefera, Tamirat, Abdissa, Biruksew, Zeleke, Mekonnen \& Teferi, Eshetu (2014). "Parasitic Contamination of Fruits and Vegetables Collected from Selected Markets of Jimma Town, Southwest Ethiopia. International Scholarly Research Notices, 7 pages.

Tetens, I. \& Alinia, S., (2009). "The role of fruit consumption in the prevention of obesity". Journal of Horticultural Science \& Biotechnology, 4, 47-51.

Wedajo, B., \& Kadire, A. (2019). Assessment of Bacterial Load of Some Fresh and Packed Fruit Juices in Arba Minch Town, Ethiopia. Journal of Nutrition and Food Sciences, 9, 759.

Whitney-Chanex, E., (2011). "The nutritional value of juices, carrots, beets, apple and celery". Food and drink nutrition. www.livinstrong.com. 